\title{
Biological testing of a digested sewage sludge and derived composts
}

\author{
R. Moreira *, J.P. Sousa, C. Canhoto \\ IMAR-Coimbra Interdisciplinary Centre, Department of Zoology, University of Coimbra, Largo Marquês de Pombal, 3004-517 Coimbra, Portugal
}

\section{A R T I C L E I N F O}

Article history:

Received 13 July 2007

Received in revised form 18 February 2008

Accepted 28 February 2008

Available online $\mathrm{xxxx}$

\section{Keywords:}

Digested sewage sludge

Compost

Avoidance tests

Reproduction tests

Germination and growth tests

\begin{abstract}
A B S T R A C T
Aiming to evaluate a possible loss of soil habitat function after amendment with organic wastes, a digested sewage sludge and derived composts produced with green residues, where biologically tested in the laboratory using soil animals (Eisenia andrei and Folsomia candida) and plants (Brassica rapa and Avena sativa). Each waste was tested mimicking a field application of 6 ton/ha or 12 ton/ha. Avoidance tests did not reveal any impact of sludge and composts to soil biota. Germination and growth tests showed that application of composts were beneficial for both plants. Composts did not affect earthworm's mass increase or reproduction, but the highest sludge amendment revealed negative effects on both parameters. Only the amendment of composts at the highest dose originated an impairment of springtails reproductive output. We suggest that bioassays using different test species may be an additional tool to evaluate effects of amendment of organic wastes in soil. Biological tests are sensitive to pollutants at low concentrations and to interactions undetected by routine chemical analysis.
\end{abstract}

(c) 2008 Elsevier Ltd. All rights reserved.

\section{Introduction}

Sewage sludge is an organic waste that gained considerable importance in European Union during the last decade, due to the implementation of Directive 91/271/EC (Domene et al., 2007). This waste is usually applied in agriculture for fertilization purposes in accordance to Directive 86/278/EC, which establishes the requirements for sludge application to soil based only on concentrations of six heavy metals: cadmium, cupper, nickel, lead, zinc and mercury. Portugal, as EU country, adapted the referred legislation to its internal law, following the requirements imposed by the European juridical ordainment. Recently, the Portuguese legislators included threshold limits for some organic substances, and set up a maximum application limit of 6 ton/ha (dry matter) of sewage sludge in agricultural soils, which can be increased if metal concentrations are bellow the respective limits (Decreto-Lei no. 118/ 2006). Portuguese legislation also imposed that the sewage sludge must be treated to ensure the reduction of fermentative activities and the elimination of pathogenic microorganisms before its use in agricultural fertilization. European and Portuguese legislation limit the use of sludge based on concentrations of pollutants individually, but do not consider the interactions between them. In spite of the positive effects on crops resulting from sludge use in agriculture, little is known about real impacts on soil system as a whole.

Bioassays have been used to study soil contamination by organic waste amendments using higher plants, like oat (Avena sativa)

\footnotetext{
* Corresponding author. Tel.: +351967023161

E-mail address: rui.jesus.moreira@gmail.com (R. Moreira).
}

and turnip (Brassica rapa) (Gong et al., 2001; Riepert and Felgentreu, 2002). However, few works have reported the use of bioassays using soil animals to test impacts of sludges and compost applications on soil. Crouau et al. (2002) and Domene et al. (2007) used soil collembolans (Folsomia candida) to test these impacts. Alvarenga et al. (2006) used earthworms (Eisenia fetida) and plants (Leptidium sativum and Hordeum vulgare) in a similar study.

The aim of the present work was to test a possible loss of habitat function of the soil (ISO 15799, 2003), when amended with (a) a digested sewage sludge, (b) four derived composts, produced with mixtures using corn-cobs, grape vine (Vitis vinífera) leaves and grass clippings, and (c) two other composts that were produced only from grape vine leaves or grass clippings. Each waste was tested to evaluate effects on the avoidance behaviour and reproduction of springtails ( $F$. candida) and earthworms (Eisenia andrei), and also the effects on the germination and growth on higher plants (A. sativa and B. rapa).

\section{Methods}

\subsection{Soil-wastes mixtures}

Six composts and a digested sewage sludge were tested at 6 and 12 ton/ha in OECD artificial soil and adapting conventional ecotoxicological assays. The parental materials of composts were $V$. vinífera leaves (collected in several agricultural private properties), grass clippings (supplied by local municipal authorities), corn-cobs (provided by a local corn producer) and digested sewage sludge. This sludge was obtained from Choupal Sewage Treatment Plant (in Coimbra) after anaerobic co-digestion of primary (decantation) 
and secondary (trickling filters) sewage sludge, during 20 days at $37{ }^{\circ} \mathrm{C}$. All materials were blended in proportions $(\mathrm{v} / \mathrm{v})$ described in Table 1.

Composting was conducted in heaps (of $1.2 \mathrm{~m}^{3}$ ) inside a $96 \mathrm{~m}^{2}$ $(4 \mathrm{~m} \times 24 \mathrm{~m})$ greenhouse. Heaps were turned weekly for a maximum period of 94 days. Resulting composts were stored at $4{ }^{\circ} \mathrm{C}$ until needed.

Artificial soil was prepared according to OECD guidelines (OECD, 1984) by mixing $10 \%$ of Sphagum peat previously sieved (5 mm mesh) and air dried, with 20\% kaolinite clay and 70\% sand quartz ( $80 \%$ particle size between 2 and $0.2 \mathrm{~mm}$ ). Soil pH was adjusted to $6 \pm 0.5$ with calcium carbonate. Before mixing with the soil, composts were sieved ( $5 \mathrm{~mm}$ mesh) and air dried. The artificial soil was amended at two different doses of each material (sludge or composts) -6 and 12 ton/ha (dry weight) - representing the recommended and the double recommended dose for sludge amendment into soil according to its metal content. These doses (expressed in a area basis) correspond to $4 \mathrm{~g} / \mathrm{Kg}$ and $8 \mathrm{~g} / \mathrm{Kg}$, respectively (the conversion was made using a soil density of $1.5 \mathrm{~g} / \mathrm{cm}^{3}$ and assuming a mixing in the first $10 \mathrm{~cm}$ of soil).

\subsection{Chemical and physical properties of wastes}

Metal contents and several chemical and physical parameters were analyzed in the sewage sludge and in the final composts (Tables 2 and 3). Organic carbon was derived as suggested by Haug (1993). Total nitrogen was determined by Kjeldhal method, and to-

Table 1

Constituent materials of each composting pile

\begin{tabular}{lllllll}
\hline $\begin{array}{l}\text { Composting } \\
\text { pile }\end{array}$ & $\begin{array}{l}\mathrm{L} \\
(\%)\end{array}$ & $\begin{array}{l}\mathrm{G} \\
(\%)\end{array}$ & $\begin{array}{l}\mathrm{C}+\mathrm{S} \\
(\%)\end{array}$ & $\begin{array}{l}\mathrm{L}+\mathrm{C}+\mathrm{S} \\
(\%)\end{array}$ & $\begin{array}{l}\mathrm{G}+\mathrm{C}+\mathrm{S} \\
(\%)\end{array}$ & $\begin{array}{l}\mathrm{L}+\mathrm{G}+\mathrm{C}+\mathrm{S} \\
(\%)\end{array}$ \\
\hline $\begin{array}{l}\text { V. vinifera } \\
\quad \text { leaves }\end{array}$ & 100 & 0 & 0 & 50 & 0 & 25 \\
$\begin{array}{l}\text { Grass } \\
\text { Corn-cobs }\end{array}$ & 0 & 100 & 0 & 0 & 50 & 25 \\
$\begin{array}{l}\text { Digested } \\
\quad \text { sludge }\end{array}$ & 0 & 0 & 50 & 25 & 25 & 25 \\
\hline
\end{tabular}

L, Vitis vinifera leaves; G, grass; C, corn-cobs; S, digested sludge. tal phosphorous was determined by Colorimetric method with ascorbic acid. The obtained values were used to derive carbon/ nitrogen ratio $(\mathrm{C} / \mathrm{N})$, nitrogen/phosphorous ratio $(\mathrm{N} / \mathrm{P})$ and carbon/phosphorous ratio $(\mathrm{C} / \mathrm{P})$ for all matrices at all sampling times. Calcium, iron, magnesium, manganese, cobalt, zinc, cupper, cadmium, lead, chromium and nickel were determined by Atomic Absorption Spectrometry (Skoog et al., 1998). Sodium and potassium were determined by flame photometry method. Electric conductivity was determined by potentiometry after water extraction (1:5). Cation exchange capacity was determined by ammonium acetate method. pH was determined by ISO 10390 (1994) method, after the suspension of substrate in $\mathrm{KCl}(1 \mathrm{M})$ solution. Moisture content was determined by differences between wet and dry weights after drying at $105^{\circ} \mathrm{C}$. Water holding capacity was determined by ISO 11269-2 (1999b). Phenols content was determined by Bärlocher and Graça (2005) method. Humic acids (HA) and fulvic acids (FA) were determined by sodium pyrophosphate method with fractions separation by $\mathrm{pH}$ variation. The humification index (HI) was derived through the ratio between humic and fulvic acids (HA/FA), as suggested by Barberis and Nappi (1993) and Tuomela et al. (2000).

\subsection{Test organisms}

Soil invertebrates and plants were used as model organisms in the assays. The earthworm $E$. andrei (Olichaeta: Lumbricidae) and the springtail $F$. candida (Collembola: Isotomidae) were used in avoidance and reproduction assays. Seed germination and plant growth tests were conducted with oat ( $A$. sativa) and turnip ( $B$. rapa). All these organisms are widely used in soil ecotoxicological studies, being sensitive to the presence of contaminants in soil (ISO 15799, 2003).

Earthworms were originated from laboratory cultures maintained in a mixture of horse manure (defaunated by freezing) and Sphagum peat. The medium was kept at a pH between 6 and 7 , adjusted with calcium carbonate $\left(\mathrm{CaCO}_{3}\right)$, and at about $60 \%$ of water holding capacity (WHC). Collembola were cultured in plastic boxes in a mixture of plaster Paris and activated charcoal, moistened with deionised water, and regularly fed with dry yeast. $B$. rapa and $A$. sativa seeds were bought at a local agriculture products store.

Table 2

Physical and chemical analysis of parental digested sewage sludge and final composts

\begin{tabular}{|c|c|c|c|c|c|c|c|}
\hline Parameter & $\mathrm{S}$ & $\mathrm{L}$ & G & $C+S$ & $\mathrm{~L}+\mathrm{C}+\mathrm{S}$ & $\mathrm{G}+\mathrm{C}+\mathrm{S}$ & $\mathrm{L}+\mathrm{G}+\mathrm{C}+\mathrm{S}$ \\
\hline $\mathrm{PH}$ & 6.7 & 7.0 & 6.7 & 6.9 & 6.8 & 6.6 & 6.7 \\
\hline Electric conductivity, $\mathrm{mS} / \mathrm{cm}$ & 4.14 & 5.11 & 4.43 & 3.63 & 2.43 & 5.92 & 5.40 \\
\hline CEC, mep/100 g & 22.80 & 33.84 & 22.16 & 22.28 & 20.16 & 19.28 & 22.48 \\
\hline Organic matter, \% & 33.76 & 32.34 & 21.04 & 15.51 & 15.92 & 15.43 & 18.50 \\
\hline Organic carbon, \% & 18.76 & 17.97 & 11.69 & 8.62 & 8.84 & 8.57 & 10.28 \\
\hline Total nitrogen, \% N & 0.56 & 1.09 & 1.04 & 0.81 & 0.81 & 0.71 & 0.90 \\
\hline Total phosphorous, $\% \mathrm{P}_{2} \mathrm{O}_{5}$ & 1.06 & 0.38 & 1.01 & 2.09 & 1.77 & 1.60 & 2.11 \\
\hline Total potassium, $\mathrm{mg} / \mathrm{kg} \mathrm{K} \mathrm{K}_{2} \mathrm{O}$ & 2.9 & 3.6 & 22.0 & 8.9 & 9.4 & 10.8 & 12.2 \\
\hline Total calcium, mg/kg CaO & 52.2 & 64.6 & 31.9 & 115.3 & 91.5 & 71.4 & 115.8 \\
\hline Total magnesium, mg/kg Mg & 3.1 & 13.8 & 8.1 & 9.8 & 9.3 & 9.5 & 10.0 \\
\hline Total iron, $\mathrm{mg} / \mathrm{kg} \mathrm{Fe}$ & 5944 & 3471 & 6097 & 7538 & 7859 & 8487 & 7707 \\
\hline Total manganese, $\mathrm{mg} / \mathrm{kg} \mathrm{Mn}$ & 109 & 111 & 117 & 98 & 121 & 84 & 92 \\
\hline Total cobalt, $\mathrm{mg} / \mathrm{kg} \mathrm{Co}$ & ND & ND & ND & ND & ND & ND & ND \\
\hline Total sodium, mg/kg Na & 0.4 & 0.6 & 4.0 & 1.1 & 0.7 & 1.2 & 1.3 \\
\hline $\mathrm{C} / \mathrm{N}$ ratio & 33.49 & 16.49 & 11.24 & 10.64 & 10.91 & 12.07 & 11.42 \\
\hline $\mathrm{N} / \mathrm{P}$ ratio & 0.53 & 2.87 & 1.03 & 0.46 & 0.46 & 0.44 & 0.43 \\
\hline $\mathrm{C} / \mathrm{P}$ ratio & 17.69 & 47.29 & 11.57 & 4.12 & 4.99 & 5.36 & 4.87 \\
\hline Humic acids (\%) & 0.6 & 2.0 & 4.3 & 2.6 & 1.9 & 1.7 & 2.5 \\
\hline Fulvic acids (\%) & 1.0 & 2.7 & 2.1 & 2.2 & 1.8 & 1.6 & 1.8 \\
\hline Humification index & 0.60 & 0.74 & 2.05 & 1.18 & 1.06 & 1.06 & 1.39 \\
\hline WHC (\%) & 249.54 & 198.44 & 115.77 & 94.09 & 96.43 & 95.79 & 97.49 \\
\hline Total phenols, eq TA/g & 0.88 & 1.62 & 0.51 & 0.94 & 0.96 & 0.53 & 1.05 \\
\hline
\end{tabular}

S, digested sewage sludge; L, Vitis vinífera leaves; C, corn cobs; G, grass clippings. 
Table 3

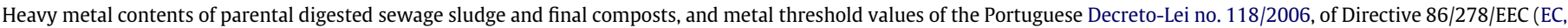
1986), of the 3rd

\begin{tabular}{|c|c|c|c|c|c|c|c|c|c|c|c|c|c|}
\hline \multirow[t]{2}{*}{ Heavy metal } & \multirow[t]{2}{*}{$\mathrm{S}$} & \multirow[t]{2}{*}{$\mathrm{L}$} & \multirow[t]{2}{*}{ G } & \multirow[t]{2}{*}{$C+S$} & \multirow[t]{2}{*}{$\mathrm{L}+\mathrm{C}+\mathrm{S}$} & \multirow[t]{2}{*}{$G+C+S$} & \multirow[t]{2}{*}{$L+G+C+S$} & \multirow[t]{2}{*}{$\begin{array}{l}\text { Decreto-Lei no. } \\
118 / 2006\end{array}$} & \multirow[t]{2}{*}{$\begin{array}{l}\text { Directive } \\
86 / 278 / \text { EEC }\end{array}$} & \multirow{2}{*}{$\begin{array}{l}\text { Directive } \\
\text { proposal } \\
\text { on sludge } \\
\left(3^{\circ} \text { Draft) }\right.\end{array}$} & \multicolumn{3}{|c|}{$\begin{array}{l}\text { Directive proposal on } \\
\text { biowaste treatment (2nd } \\
\text { Draft) }\end{array}$} \\
\hline & & & & & & & & & & & Class 1 & Class 2 & $\begin{array}{l}\text { Stabilized } \\
\text { biowaste }\end{array}$ \\
\hline Total zinc, mg/kg Zn & 500 & 30 & 61 & 230 & 338 & 164 & 217 & 2500 & $2500-4000$ & 2500 & 200 & 400 & 1500 \\
\hline Total cupper, mg/kg Cu & 124 & 102 & 16 & 96 & 94 & 76 & 95 & 1000 & $1000-1750$ & 1000 & 100 & 150 & 600 \\
\hline Total cadmium, mg/kg Cd & ND & ND & ND & ND & ND & ND & ND & 20 & $20-40$ & 10 & 0.7 & 1.5 & 5 \\
\hline Total lead, mg/kg Pb & 48 & ND & ND & ND & ND & ND & ND & 750 & $750-1200$ & 750 & 100 & 150 & 500 \\
\hline Total chromium, mg/kg Cr & 29 & 9 & 18 & 30 & 29 & 25 & 27 & 1000 & Not Defined & 1000 & 100 & 150 & 600 \\
\hline Total nickel, mg/kg Ni & 15 & ND & ND & ND & ND & ND & ND & 300 & $300-400$ & 300 & 50 & 75 & 150 \\
\hline
\end{tabular}

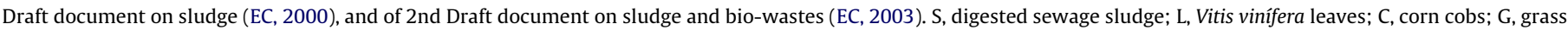
clippings.

\subsection{Avoidance tests}

The earthworm's avoidance test was based on ISO 17512-1 (2005a). Each replicate consisted of a plastic container $(20 \mathrm{~cm}$ length, $12 \mathrm{~cm}$ width, $5 \mathrm{~cm}$ height) divided in two equal sections by a removable plastic card. One side was filled with $250 \mathrm{~g}$ (dry weight) of OECD soil, while the other was filled with $250 \mathrm{~g}$ (dry weight) of OECD soil-waste mixture. After removing the divider card, 10 adult earthworms were placed in the middle line. To prevent animals from escaping, the test containers were covered with a perforated lid. At the end of the assay (after $48 \mathrm{~h}$ of exposure), the plastic divider was reintroduced in the container's middle line, and the content of each side was emptied onto two different trays, and organisms of each side were counted. The organisms found at the underside of the lid were considered dead, and the organisms found in the middle line were accounted as 0.5 for each side. To check for the homogeneous distribution of animals when the same medium is placed on both sides of the test container, "dual control tests" were preformed with OECD soil.

Avoidance tests with springtails followed the same principle and were based on the ISO 17512-2 (2005b). Each replicate consisted of a plastic container $(7 \mathrm{~cm}$ diameter, $6 \mathrm{~cm}$ height) divided in two equal sections by a removable plastic card. One side was filled with $30 \mathrm{~g}$ (dry weight) of OECD soil, while the other side was filled with $30 \mathrm{~g}$ (dry weight) of OECD compost or OECD-sludge mixture. Twenty springtails (10-12 days old) were placed in the middle line after removing the divider card. To prevent them from escaping, the test containers were covered with a perforated lid. At the end of the assay ( $48 \mathrm{~h}$ ), the plastic divider was reintroduced in the middle line, and the container was covered with a half lid and the content of one side was emptied to another vessel. Then, both containers were filled with water and coloured by adding some drops of blue ink. After stirring, the number of organisms present in each container was counted. As for the earthworms, also in this case, a "dual control test" was performed, and where both sides of the plastic containers were filled with $30 \mathrm{~g}$ (dry weight) of OECD soil. In all avoidance tests, for both species, soil $\mathrm{pH}$ and moisture content were measured at the beginning and at the end of the tests.

\subsection{Reproduction tests}

Earthworm reproduction test was based on the ISO 11268-2.2 (1998). Each replicate consisted in a plastic container $(11 \mathrm{~cm}$ diameter, $12 \mathrm{~cm}$ height) filled with $500 \mathrm{~g}$ (dry weight) of OECD compost or sludge amended soil, in which 10 clitellated adult worms (250$600 \mathrm{mg}$ ) were introduced. Control treatment was made using OECD soil only. The initial moisture content of the soil was $50 \%$ of WHC, corrected weekly by spraying deionised water. To prevent animals from escaping, the test containers were covered with a perforated lid. Worms were fed weekly with $5 \mathrm{~g}$ of dried horse manure (defaunated by freezing). After 28 days, the adult earthworms were removed and weighted. Cocoons were incubated for another 28 days in order to allow hatching of juveniles. At the end of the assay, containers were heated in a water bath at $60{ }^{\circ} \mathrm{C}$ for $20 \mathrm{~min}$ to force the migration of juveniles to the surface of the soil.

For springtails, the reproduction test followed the ISO 11267 (1999a) guideline. Each replicate consisted of a glass container ( $4 \mathrm{~cm}$ diameter, $7 \mathrm{~cm}$ height) filled with $30 \mathrm{~g}$ (dry weight) of OECD compost or sludge amended soil, in which 10 synchronized juvenile sprigtails (10-12 days old) were introduced. Animals were fed at the beginning of the tests and after 14 days with $2 \mathrm{mg}$ of granulated dry yeast. Again, control treatment was made with OECD soil only. The initial moisture content of the soil was adjusted and controlled as for the earthworm tests. To prevent the escape of animals, vials were sealed, but open weekly for $5 \mathrm{~min}$ to prevent oxygen depletion. At the end of the assay, the container was emptied to another vessel. The last was filled with water and coloured with some drops of blue ink. After stirring, the vessel was photographed, and the number of adults and juvenile appearing on the surface were counted.

Both tests were conducted at $20 \pm 2{ }^{\circ} \mathrm{C}$ with a 16:8 (light:dark) photoperiod, with four replicates for earthworms and five replicates for springtails per treatment. At the beginning and at the end of both assays, soil $\mathrm{pH}$ and moisture content were determined.

\subsection{Plant germination and growth}

The germination and growth test was based on the ISO guideline 11269-2 (1999b). Each replicate consisted of a plastic container (9 cm length, $12 \mathrm{~cm}$ width, $6 \mathrm{~cm}$ height) filled with $350 \mathrm{~g}$ (dry weight) of OECD compost or sludge amended soil. Controls run with OECD soil. To ensure a suitable test substrate moisture along the experimental time, each container was perforated and connected to a vessel filled with deionised water by a glass fibre wick. Before the introduction of plants seeds, each test container was left during $24 \mathrm{~h}$ to allow the moistening of the test substrate. Thereafter, 10 seeds were buried to a depth of $1 \mathrm{~cm}$. After seed germination, growth was allowed for 21 days in B. rapa and 19 days in A. sativa. At the end of the assay, the aerial parts of all plants were cut, dried during $48 \mathrm{~h}$ at $50{ }^{\circ} \mathrm{C}$, and weighted. The assays were carried out in a greenhouse, at an average temperature of $22^{\circ} \mathrm{C}(\max -$ imum $33^{\circ} \mathrm{C}$ and minimum $19^{\circ} \mathrm{C}$ ), at an average air relative humidity of $70 \%$ (maximum $95 \%$ and minimum 40\%) and with a natural photoperiod of 12:12 (light:dark). Soil $\mathrm{pH}$ and moisture content were determined at the beginning and at the end of the assays. 


\subsection{Statistical analysis}

Fisher Exact Test was used to analyze the results of avoidance tests with earthworms and springtails. With this procedure it is possible to compare the actual distribution of individuals with an expected distribution, assuming no avoidance as the null hypothesis (Natal-da-Luz et al., 2004; Zar, 2004).

One-way Analysis of Variance (ANOVA) was performed to compare the reproduction levels of soil animals between control soil (OECD) and the two application doses of sludge or compost spiked soils of each soil amendment. When significant statistical differences were detected $(P<0.05)$, Dunnet's Test was used to identify significant differences between the different treatments and controls. The same statistical treatment was applied to germination and growth test results (Zar, 2004). STATISTICA 6.0 software was used for all statistical analysis.

\section{Results}

\subsection{Avoidance tests}

In the avoidance tests with earthworms no mortality was observed. Significant statistical differences were found between OECD soil and OECD amended soils (with compost or sludge) at both 6 ton/ha (Fig. 1A) and 12 ton/ha (Fig. 1B). A clear preference pattern for amended soils in relation to OECD soil was observed, especially in the highest compost dose (12 ton/ha). In case of the digested sludge, the referred preference was only statically significant at the application of 12 ton/ha. In the "dual control test", comparing OECD soil vs. OECD soil, no statistical differences were found, indicating the homogeneous distribution of the earthworms among the two sides of the test chamber.
Like in the earthworms, no mortality was observed in avoidance tests with springtails. However, a different response pattern was observed (Fig. 2A and B). On both doses tested, significant differences were found between OECD soil and OECD soil amended with grass clippings $(\mathrm{G})$ and Vitis vinifera leaves (L) composts, showing the organisms preference for those compost-soil mixtures. In the "dual control test", also no statistical differences were found.

\subsection{Reproduction tests}

The earthworm reproduction test was considered valid under the criteria established in the guideline ISO 11268-2 (1998), i.e., juvenile production per control container higher than 30 animals (mean of 248 earthworms per container test), coefficient of variation lower than $30 \%$ (around $11 \%$ in this case) and mortality lower than $10 \%$ (null, in this case).

A significant higher increase of adult earthworm's weight after 28 days was found on both tested doses of compost $\mathrm{L}$, when compared to the control treatment (Fig. 3A). An inverse response, but also statistically significant, was found in adult earthworms exposed to the 12 ton/ha dose of sludge, indicating an impairment of weight gain of adult animals when compared to the control. No statistical differences were found when weight increase in the remainder dosages were compared with the one observed in control.

Similar results were observed in the production of juveniles (Fig. 3B). Significant statistical differences were found in applications of both tested doses of $\mathrm{L}$ compost, revealing a higher number of juveniles than in control. Also, statistical differences were detected in 12 ton/ha dose of sludge, indicating that the number of juveniles was lower than in control. No statistical differences were found in the other wastes and concentrations when compared with the number of juveniles verified in control.
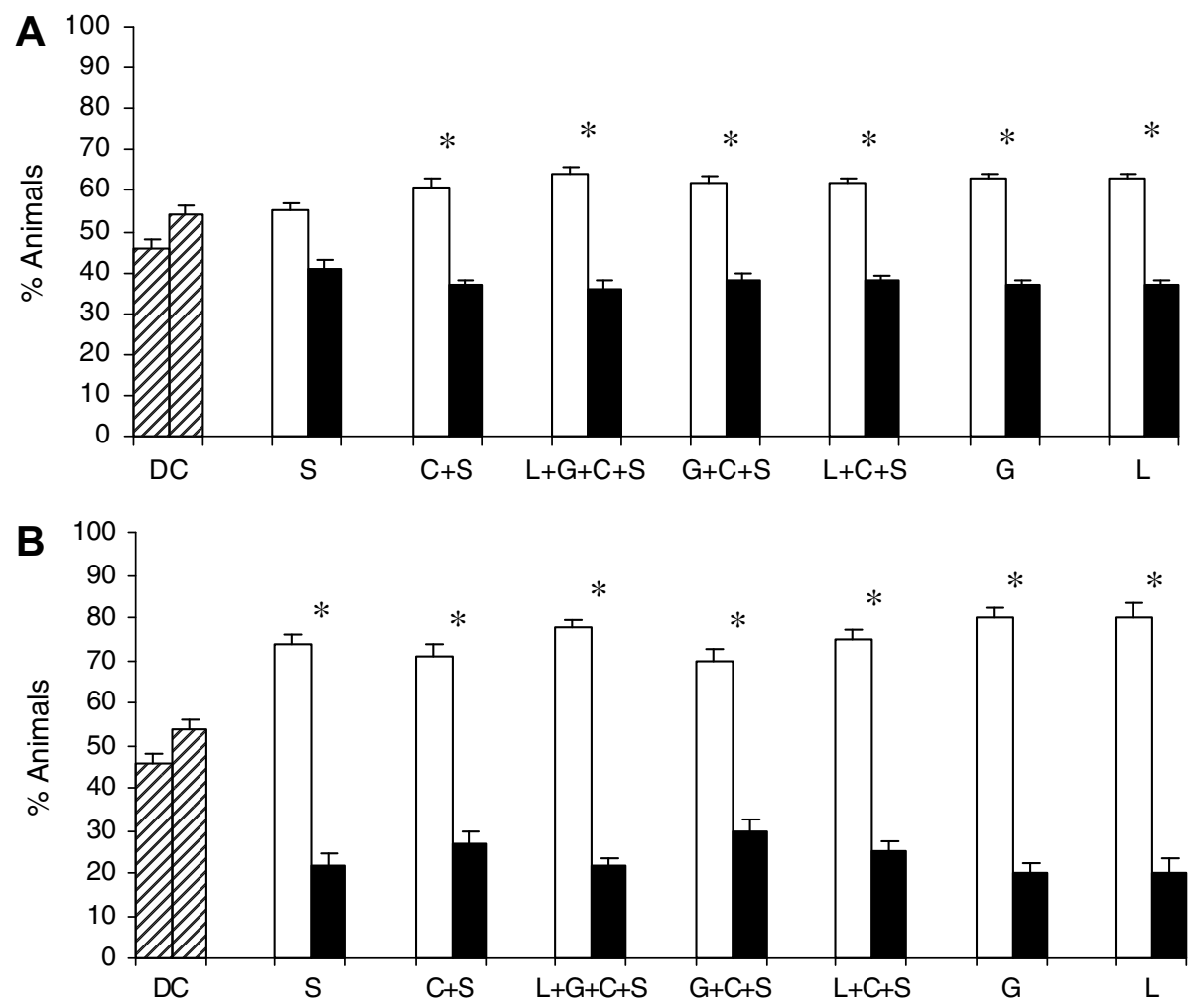

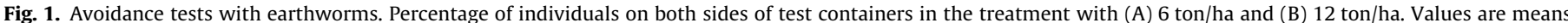

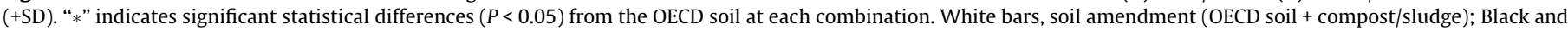
shaded bars, OECD soil; DC, dual control test (see text for more information); C, corn-cobs; G, grass clippings; L, Vitis vinifera leaves; S, sludge. 

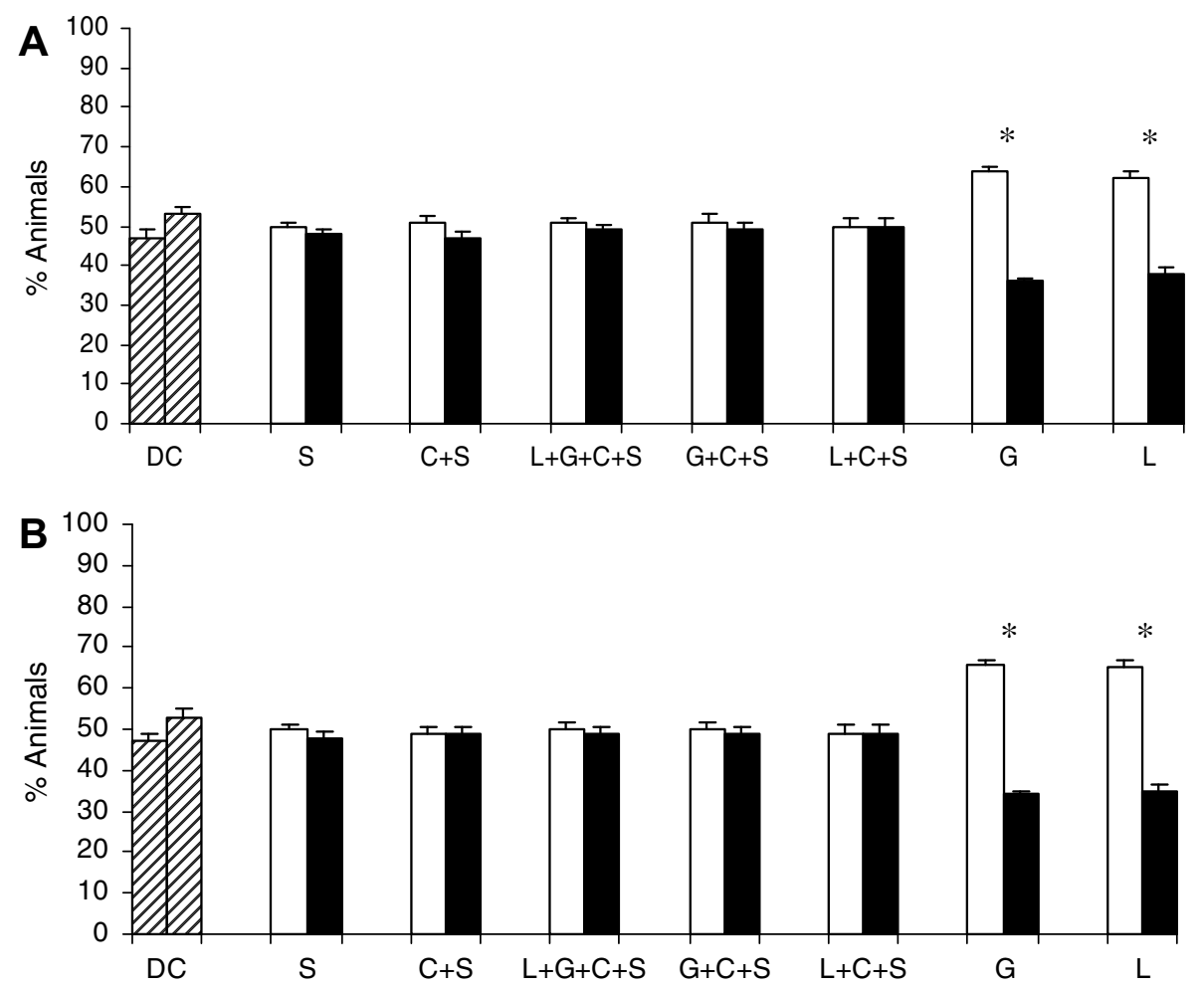

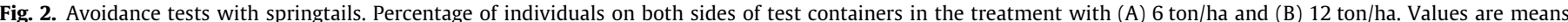

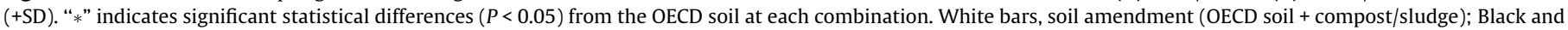
shaded bars, OECD soil; DC, dual control test (see text for more information); C, corn-cobs; G, grass clippings; L, Vitis vinifera leaves; S, sludge.
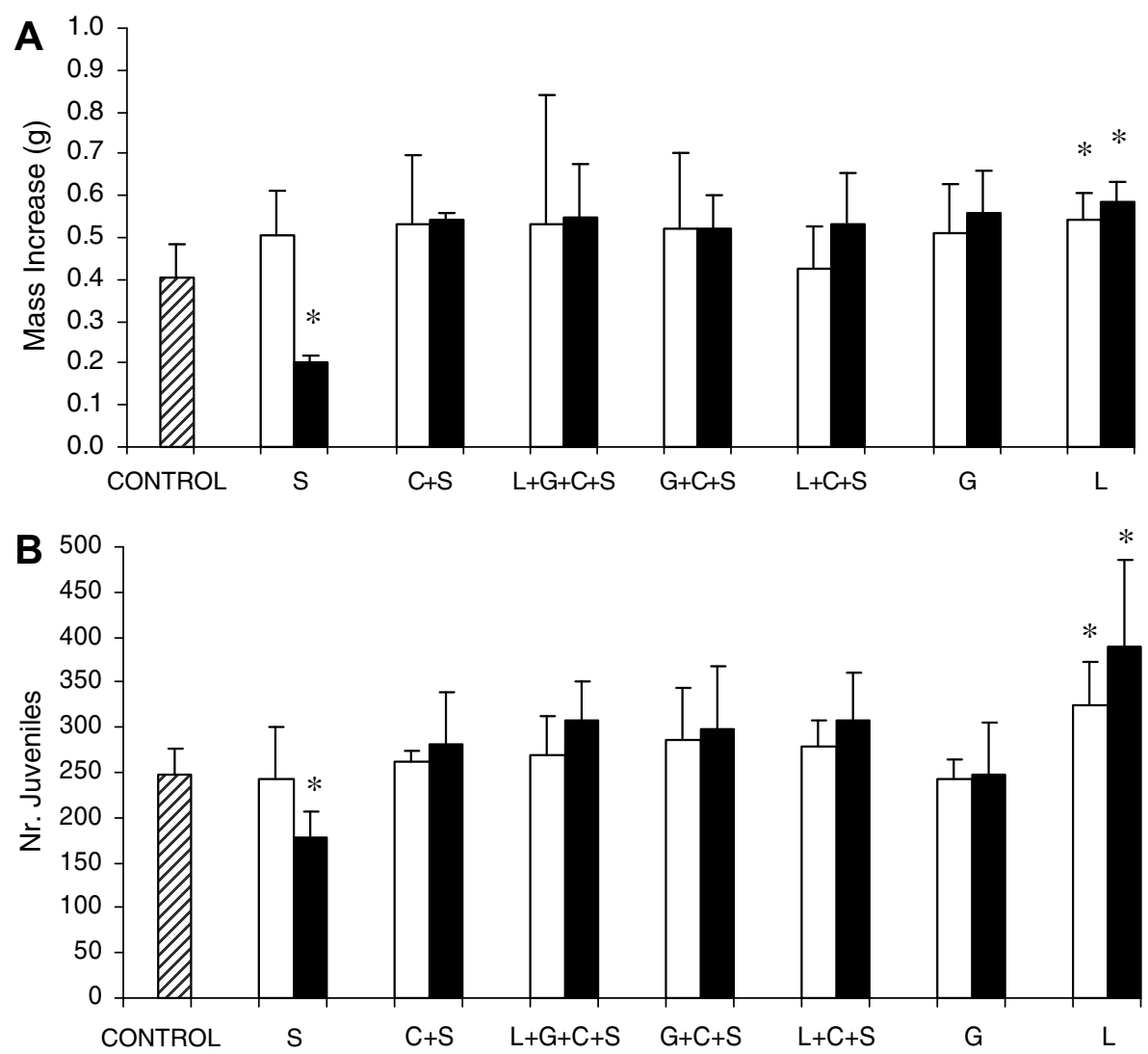

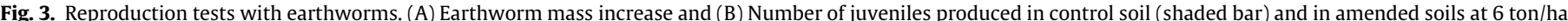

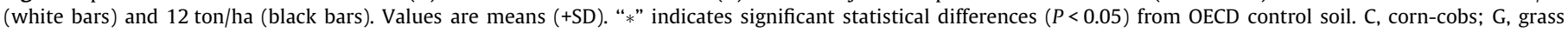
clippings; L, Vitis vinifera leaves; S, sludge.

Please cite this article in press as: Moreira, R. et al., Biological testing of a digested sewage sludge and derived composts, Bioresour. Technol. (2008), doi:10.1016/j.biortech.2008.02.046 


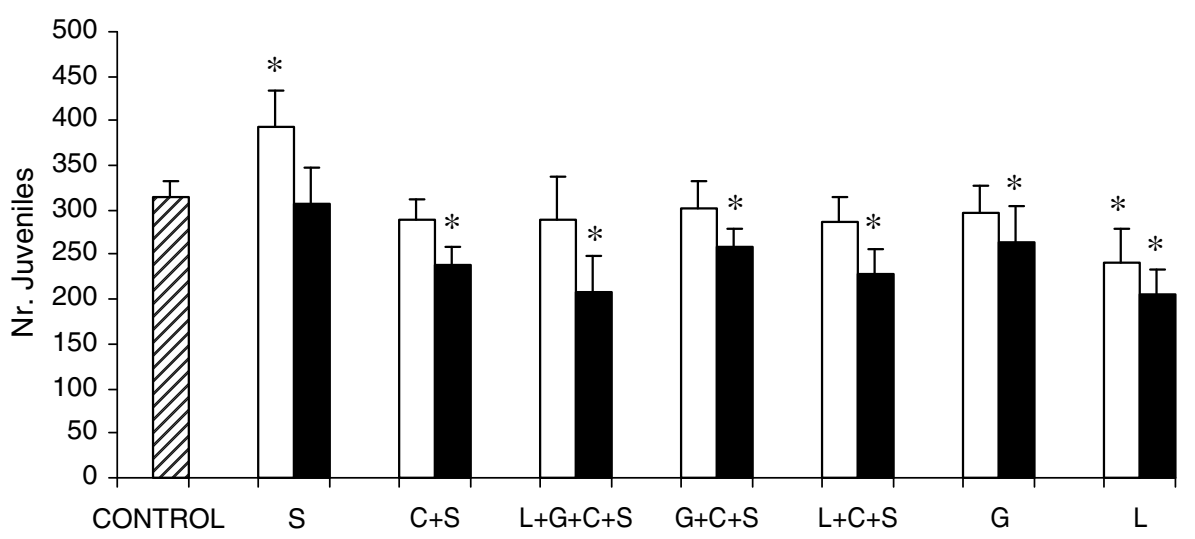

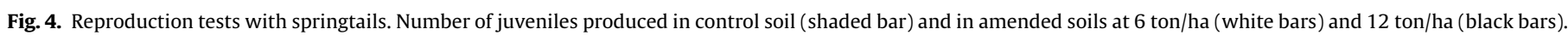

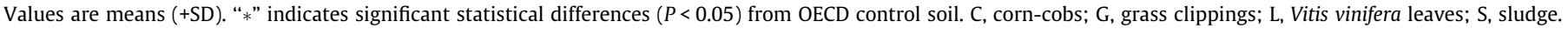

The springtail reproduction test also complied with all requirements of the ISO guideline 11267 (1999a), given that the mortality of adults was lower than $20 \%$ at the end of the test (10\%), the reproduction rate was higher than 100 instars per control vessel (mean value of 315 individuals per control container) and the coefficient of variation of reproduction was lower than $30 \%$ (a value of $5.6 \%$ was observed).

No statistical differences were found when comparing the number of surviving adults placed in control and in OECD soil amended with 6 ton/ha and 12 ton/ha of sludge or compost treatments. The exception occurred in soil amended with 12 ton/ha of compost L, where a significantly lower survival rate was observed.

The highest number of juvenile springtails was observed in soil amended with 6 ton/ha of sludge (Fig. 4), where statistical differences were found when compared with the control. The lowest number of juvenile springtails was observed in soil amended with 12 ton/ha of $\mathrm{L}$ compost, where statistical differences were also found in comparison with the control. This significant impairment in juvenile production was common to all soil amendments at 12 ton/ha, with the exception on the soil amended with the sludge. This response was not observed at 6 ton/ha, with the exception of the soil amended with the L compost.

\subsection{Germination and growth tests}

The emergence of oat (77.5\%) and turnip (87.5\%) was enough to provide five healthy seedlings per control vessel, fulfilling the requirements of the guideline ISO 11269-2 (1999b). Seed germination of both test species on all compost and sludge treatments was similar to the respective controls, for both doses tested, and no statistical differences were detected.

Regarding oat plant mass increase (Fig. 5A), significant statistical differences from the control soil were found at the $S$ and $L$ treatments (on both doses tested), and also on the $\mathrm{L}+\mathrm{G}+\mathrm{C}+\mathrm{S}$ and $\mathrm{G}$ composts (at the 12 ton/ha only), all with a higher plant mass. In the other treatments, no significant statistical differences from the control were detected.

A different pattern was observed in mass increase of turnips (Fig. 5B), where a higher plant biomass was observed in almost all treatments and doses tested, when compared with the control treatment. The only exception occurred in the $\mathrm{C}+\mathrm{S}$ compost at the dose of 6 ton/ha.

\section{Discussion}

\subsection{Avoidance tests}

Avoidance tests with both earthworms and springtails did not reveal any negative effect in none of the treatments tested at both doses, since no avoidance behaviour was observed for both test organisms. Earthworms showed even a clear preference for sludge and compost amended soils, which was more evident at 12 ton/ha applications. In springtails, a preference behaviour was only observed for the composts made only with $V$. vinifera leaves (L) or grass clippings $(G)$, whereas in the other treatments no differences were observed between the amended soil and the corresponding OECD control soil.

This lack of avoidance response towards the amended soils cannot exclude the existence of an impairment of the habitat function caused either by the metals or the phenolic compounds present in the plant material. When testing combinations of soils with different organic matter content, Natal-da-Luz et al. (2008) observed a preference behaviour by these two test species (particularly by the earthworms) for soils with the highest organic matter content. This response is stronger if the difference between soils is high, and can even occur if the soil with the higher organic matter content is contaminated (Natal-da-Luz et al., 2004). In this context, the behaviour observed in this study may be explained by the higher organic matter content of OECD amended soils when compared with simple OECD soil.

\subsection{Reproduction tests}

In earthworm reproduction test, no negative effects were observed in weight increase or in the number of juveniles produced in most of the treatments and at both doses tested. Positive effects were observed in soil amended with both doses of the $V$. vinifera compost, but an impairment on weight increase and reproduction was observed in the soil amended with the highest dose of sludge alone. The differences observed between the results obtained with parental sludge and those obtained with composts might be explained either by the dilution effect caused by the mixture of sludge with green wastes, that might have masked the toxic effect of some compounds present in the parental sludge and not chemically determined (Crouau et al., 2002), or by the degradation or transformation of those toxic compounds to less harmful substances during the composting process (Crouau et al., 2002; Eweis et al., 1999).

A different response was observed in springtails. These organisms showed a higher sensitivity to the compost amendments in comparison to the earthworms. Reproduction was impaired in all composts at the highest dose tested and, in the soil amended with the $V$. vinifera compost, even at the dose of 6 ton/ha the number of juveniles produced was lower than in the control treatment. This negative effect on springtails reproduction was unexpected, since in avoidance tests this species showed a clear preference for this compost in relation to OECD soil. Surprisingly, the parental sludge 

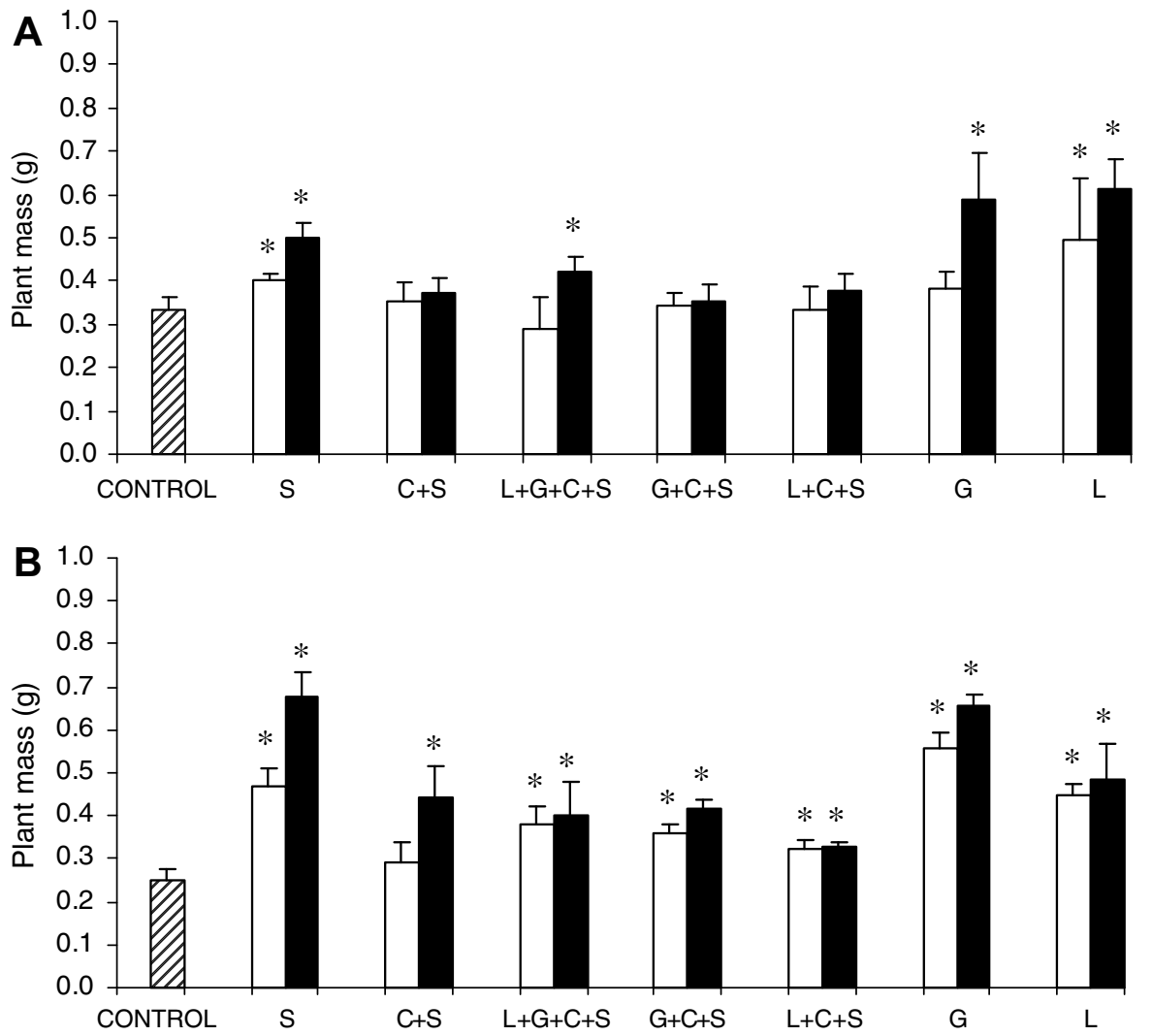

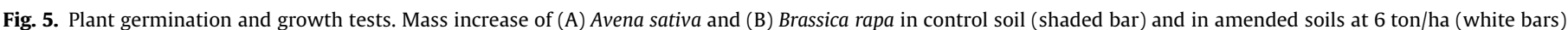

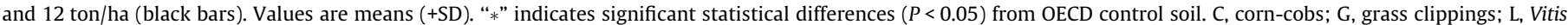
vinifera leaves; $\mathrm{S}$, sludge.

seems to affect less springtails than composts did, in spite of its higher concentration of zinc ( $500 \mathrm{mg} / \mathrm{Kg}$ ) which is known to have negative effects on reproduction at concentrations higher than $50 \mathrm{mg} / \mathrm{kg}$ (Fountain and Hopkin, 2005).

The negative effect caused by the $V$. vinifera compost on reproduction might be related to its higher content of phenols (Fountain and Hopkin, 2005). Moreover, the low number of juveniles observed in the other composts could be related to non-analyzed substances that, when present in the highest dose tested, originated the observed effects. According to Crouau et al. (2002), results obtained in bioassays of wastes with $F$. candida should be carefully interpretated, since variations in $\mathrm{pH}$, organic matter content, humidity and characteristics of test soils can lead to differences on its reproductive output.

\subsection{Germination and growth tests}

The application of sludge and composts showed no interference in seed germination of A. sativa and B. rapa. These results were expected, since in earlier stages of plant development their nutrition is provided by seed materials, and because the chemical quality of those soil amendments (low heavy metal concentrations) was apparently good (Alvarenga et al., 2006; Mauseth, 2003).

Dry weight increase of plants in amended soils was higher than those observed in the control soil. This positive effect on growth agrees with the known increase in crop fertility with the addition of sludge or composts (Mauseth, 2003). According to our results, higher doses produced larger plants, what is a desirable effect in agriculture. In addition, wastes with higher organic content (sewage sludge and $\mathrm{G}$ and $\mathrm{L}$ composts) allowed the growth of the largest plants. Some authors (MacCarthy et al., 1990; Mustin, 1987) attribute compost fertility enhancements to their slow release of nutrients to the soil, which improves its microbial activity and, consequently, plant growth. They also refer that organic matter present in composts is beneficial to the soil, increasing its water holding capacity, acting as buffer against $\mathrm{pH}$ changes, improving the aggregation between silt and clay particles and augmenting the retention of metal micronutrients (limiting their leaching).

\subsection{The use of biological tests as a selection criteria for bio-wastes}

Due to the need to regulate the use of sewage sludges as soil fertilizers, the European Union, through Directive 86/278/EEC (EC, 1986), has established threshold values for the heavy metal content in the sludge material. These values are still under revision, aiming to decrease some of the metal limits established earlier. In Portugal, the limit values for pollutants allowing the agricultural application of sludge are defined by the Decreto-Lei no.118/2006.

The parental sludge used in this study fulfilled the Portuguese and the current (EC, 1986) and proposed (EC, 2000) European metal limit values for sludge application in agricultural soils (Table 3 ). Also according to the limit values proposed on the working document for bio-wastes (EC, 2003), the composts derived from green wastes ( $L$ and $G$ ) and compost $G+C+S$ fulfilled the requirements of the Class 1 category (best), while the remaining composts were classified in the Class 2 category (second best) due to zinc concentrations.

However, despite the absence of high metal loadings on the parental sludge and of the good classification given to the composts, the results obtained in some of the biological assays revealed an impairment of soil habitat function after their amendment into soil. Although this effect was most visible at the higher dose tested, it stresses the need to incorporate this type of biological evaluation as a complementary criteria for selecting bio-wastes to use as soil 
fertilizers in agriculture and soil restoration. Moreover, the different sensitivity revealed by different tests and test organisms indicates that a test battery should be used in this evaluation, in order to capture the possible effects caused by the multiple contaminant profiles that could be found in different sludge types and derived composts.

In our study the reproduction tests were the most sensitive, whereas avoidance tests were strongly influenced by the organic matter content of the amended soil. This reveals that extra research is needed either in order to develop correction factors allowing a control of the influence of soil properties in the avoidance response, or in order to define avoidance tests as a simple screening tool to evaluate strong harmful effects.

The need to incorporate biological tests in the assessment of the toxic potential of organic wastes was already mentioned in several scientific and technical documents (e.g., Domene et al., 2007). Similarly to the effort being developed for the toxicological evaluation of wastes under the Council Directive 91/686/EEC (Pandard et al., 2005), a strong effort should be attempted for this type of biowastes.

\section{Conclusions}

The results obtained in this study indicate that biological tests are useful and essential to predict the impacts of amendments with some organic wastes into soils. The dose of 6 ton/ha suggested in Portuguese legislation seems to be a safe amendment in this case. However, it must be underlined that, despite the acceptable values in all chemical parameters analyzed both on the parental sludge and derived composts, biological tests revealed that this apparent harmless was not completely real. However, excluding phenols, other organic toxicants that could be present in higher levels than the permitted, were not analyzed. In any case, the performance of biological assays allowed to detect effects of contaminants not analyzed or even possible interactions between pollutants that can be present at concentration below the recommended values. Thus, bioassays can be a complementary toolbox useful for the early detection of ecotoxicological risks of soil amendments with organic wastes, allowing to obtain a more complete view of the possible effects, not given solely by chemical analysis.

\section{Acknowledgements}

The authors are grateful to Tiago Natal-da-Luz (for precious help in all ecotoxicological assays), Júlia Niemeyer and Alexandre Wegner (for precious help in earthworms reproduction tests and germination and growth assays), to António Veiga Simão (Director of Environmental Department of Coimbra's Municipal Authority for the greenhouse), and to Carlos Moita (for the anaerobic digested sludge). We also thank two anonymous reviewers for their comments and suggestions on an earlier version of the manuscript.

\section{References}

Alvarenga, P., Palma, P., Gonçalves, A., Fernandes, R., Cunha-Queda, A., Duarte, E., Vallini, G., 2006. Evaluation of chemical and ecotoxicological characteristics of biodegradable organic wastes for application to agricultural land. Environmental International 33, 505-513.

Barberis, R., Nappi, P., 1993. Evaluation of compost stability. In: Bertoldi, M., Sequi, P., Lemmes, B., Papi, T. (Eds.), The Science of Composting. Blackie Academic \& Professional, Glasgow, pp. 175-184.
Bärlocher, F., Graça, M., 2005. Total phenolics. In: Graça, M., Bärlocher, F., Gessner, M. (Eds.), Methods to Study Litter Decomposition. Springer, Netherlands, pp. 97-100.

Crouau, Y., Gisclard, C., Perotti, P., 2002. The use of Folsomia candida (Collembola Isotomidae) in bioassays of waste. Applied Soil Ecology 19, 65-70.

Decreto-Lei no. 118/2006, de 21 de Junho. Diário da Republica. I Série. Ministério do Ambiente, do Ordenamento do Território e do Desenvolvimento Regional. Lisboa, 2006

Domene, X., Alcañiz, J., Andrés, P., 2007. Ecotoxicological assessment of organic wastes using the soil collembolan Folsomia candida. Applied Soil Ecology 35, 461-472.

EC (European Commission), 1986. Council Directive 86/278/EEC of 12 June 1986, on the protection of environment, and in particular of the soil, when sewage sludge is used in agriculture. OJ L, 181.

EC (European Commission), 2000. Working Document on Sludge - 3rd. Draft. Directorate-General Environment. Brussels, DG ENV.E.3/LM.

EC (European Commission), 2003. Working Document on Sludge and Biowaste 2nd Draft. Directorate-General Environment. Brussels, DG ENV.A.2/LM.

Eweis, J., Ergas, S., Chang, D., Schroeder, E., 1999. Principios de Biorrecuperación. MacGraw-Hill/Internamericana de Espana, Madrid.

Fountain, M., Hopkin, S., 2005. Folsomia candida (Collembola): a standard soil arthropod. Annual Reviews of Entomology 50, 201-222.

Gong, P., Wilke, B., Strozzi, E., Fleischmann, S., 2001. Evaluation and refinement of a continuous seed germination and early seedling growth test for use in ecotoxicological assessment of soils. Chemosphere 44, 491-500.

Haug, R., 1993. The Practical Handbook of Composting Engineering. Lewis, Publishers, Boca Raton.

ISO (International Organization for Standardization), 1994. Soil quality Determination of pH. ISO 10390. Geneve, Switzerland.

ISO (International Organization for Standardization), 1998. Soil quality - Effects of pollutants on earthworms (Eienia fetida) - Part 2: Determination of effects on reproduction. ISO 11268-2. Geneve, Switzerland.

ISO (International Organization for Standardization), 1999a. Soil quality - Inhibition of reproduction of Collembola (Folsomia candida) by soil pollutants. ISO 11267. Geneve, Switzerland.

ISO (International Organization for Standardization), 1999b. Soil quality Determination of effects of pollutants on soil flora. Part 2: Effects of chemicals on the emergence and growth of higher plants. ISO 11269-2. Geneve, Switzerland.

ISO (International Organization for Standardization), 2003. Soil quality - Guidance on the Ecotoxicological Characterization of Soils and Soil Materials. ISO 15799. Geneve, Switzerland.

ISO (International Organization for Standardization), 2005a. Soil quality Avoidance test for testing the quality of soils and effects of chemicals on behaviour - Part 1: Test with earthworms (Eisenia fetida and Eisenia andrei). ISO 17512-1 (Draft). Geneve, Switzerland.

ISO (International Organization for Standardization), 2005b. Soil quality Avoidance test for testing the quality of soils and effects of chemicals on behaviour - Part 2: Test with collembolan (Folsomia candida). ISO 17512-2 (under discussion in ISO TC 190 SC 4 WG 2 panel). Geneve, Switzerland.

MacCarthy, P., Malcolm, R., Clapp, C., 1990. Humic substances in soil and crops: selected readings. Soil Science Society, Madison.

Mauseth, J., 2003. Botany: an Introduction to Plant Biology. Jones and Bartlett, London.

Mustin, M., 1987. Le compost. Éditions François Dubusc, Paris.

Natal-da-Luz, T., Ribeiro, R., Sousa, J., 2004. Avoidance tests with collembolans and earthworms as easy screening tools for site specific assessment of polluted soils. Environmental Toxicology and Chemistry 23, 2188-2193.

Natal-da-Luz, T., Roembke, J., Sousa, J.P., 2008. Avoidance tests in site-specific risk assessment - the influence of soil properties on the avoidance response of Collembola and Earthworms. Environmental Toxicology and Chemistry 27.

OECD, 1984. Guideline for testing of chemicals - Earthworms acute toxicity tests. Organization for Economic Co-operation and Development. No. 207.

Pandard, P., Devillers, J., Charissou, A.-M., Poulsen, V., Jourdain, M.-J., Férard, J.F., Grand, C., Bispo, A., 2005. Selecting a battery of bioassays for ecotoxicological characterization of wastes. Science of the Total Environment 363, 114-125.

Riepert, F., Felgentreu, D., 2002. Relevance of soil storage to biomass development, $N$-mineralization and microbial activity using higher plants growth test, ISO 11269-2, for testing contaminated soils. Applied Soil Ecology 20, 57-68.

Skoog, D., Holler, F., Nieman, T., 1998. Principles of Instrumental Analysis, fifth ed Brooks Cole, Massachusetts.

Tuomela, M., Vikman, M., Hatakka, A., Itävaara, M., 2000. Biodegradation of lignin in a composting environment: a review. Bioresource Technology 72, 169183.

Zar, J., 2004. Biostatistical Analysis, fourth ed. Pearson Education, New Jersey. 